УДК 531:535

G. V. Banzak ${ }^{1}$, PhD, O. V. Banzak ${ }^{2}, \mathrm{PhD}$, O. I. Leshchenko ${ }^{2}, \mathrm{PhD}$

${ }^{1}$ Odessa at a port factory, c. Odessa

${ }^{2}$ Odessa State Academy of Technical Regulation and Quality, c. Odessa

\title{
INFLUENCE OF FACTOR VARIATION ON SIZE OF AN OPTIMUM LEVEL OF MAINTENANCE SERVICE
}

In clause the imitating statistical model as model of refusals of served elements on the basis of DNdistribution is offered. Researches are made in a mode of modeling of maintenance service ,on a condition” with constant periodicity of the control. By results of the lead researches the general reason that the less size of factor variation of a casual operating time to refusal of served elements, the great should be optimum value of a level of maintenance service proves to be true.

Keywords: factor of the variation, served elements, value of a level, maintenance service

Introduction. The choice of an optimum level of maintenance service (MS) $u_{\text {то } i}$ should depend on statistical properties of the defining parameter of $i$-th element. It is obvious, that the main characteristic on which the choice of optimum value $u_{\text {то } i}$ depends, the factor of a variation of the defining parameter $v_{u i}$ is. The less size $v_{u i}$, the great should be optimum value $u_{\text {то } i}$. Is complex enough problems of optimization which cannot be solved by standard exact methods of optimization. The main reasons of it are such features of these problems:

- for criterion functions analytical expressions are unknown, their values can be received only as a result of statistical modeling. Therefore the elementary can be applied to reception of the decision only methods of search extremums;

- required optimized parameters have complex structure (set $E_{\mathrm{To}}^{*}$, a vector $U_{\text {то }}^{*}$ ), that creates insuperable difficulties at attempt to search for exact decisions.

Therefore probably only the approached decision of the given problems.

The general problem at the decision of problems of optimization of maintenance service „on a condition" (MSC) is the choice of an optimum vector of levels MS $U_{\text {то }}^{*}$. The essence of this problem is analyzed in given clause.

Basic part. In the developed imitating statistical model (ISM) as model of refusals of served elements $D N$-distribution is used. Feature of $D N$ distribution is that the factor variation of distribution $v_{i}$ is equal to factor of a variation $v_{u i}$ of the defining parameter of an element which refusals generate the given $D N$-distribution $[1,2,3]$. This fact essentially simplifies research of properties of optimum levels MS $u_{\mathrm{ro} i}$. We investigate, as optimum value $u_{\mathrm{To} i}^{*}$ depends on factor of a variation of served elements $v_{i}$ on the average. Research we shall make in a mode of modeling MSC with constant periodicity of the control. For all served elements we shall set identical values of factor variations of an operating time to refusal $v_{i} \equiv v$, and to define the same optimum value $u_{\mathrm{ro} i}^{*} \equiv u_{\mathrm{To}}^{*}$. Optimum value $u_{\mathrm{To} i}^{*}$ we shall define by criterion

$$
u_{\mathrm{ro}}^{*}: c_{\text {уд }}\left(E_{\text {то }}, u_{\text {то }}, T_{\mathrm{k}}\right) \rightarrow \min _{u_{\mathrm{ro}}}
$$

where parameters $E_{\text {то }}$ also $T_{\mathrm{K}}$ are fixed.

The set $E_{\text {то }}$ is the characteristic of object, parameter $T_{\mathrm{K}}$ we shall vary in some range.

The special software (SW) is developed for carrying out of research, allowing to receive dependence of a parameter $c_{\text {уд }}\left(E_{\text {то }}, u_{\text {то }}, T_{\mathrm{k}}\right)$ on parameters interesting us. Results of calculations turn out in the form of corresponding schedules.

Research we shall lead on an example of test object Test-1. In a database (DB) for object Test-1 we shall consistently set various values of factor of a variation $v$ of distribution of an operating time to refusal of constructive elements of the bottom level. Then at each value $v$ we shall make calculations with the purpose of definition of optimum value of a level MS $u_{\mathrm{To}}^{*}$ by criterion (1).

Variation $u_{\text {то }}$ we shall make in a range $[0,1 ; 0,96]$ with an interval 0,02 . Calculations we shall make provided that set $E_{\mathrm{To}}=\{132,12,11111\}$, for three values of periodicity of the control 
Specific cost of operation, y.e. $\mu$
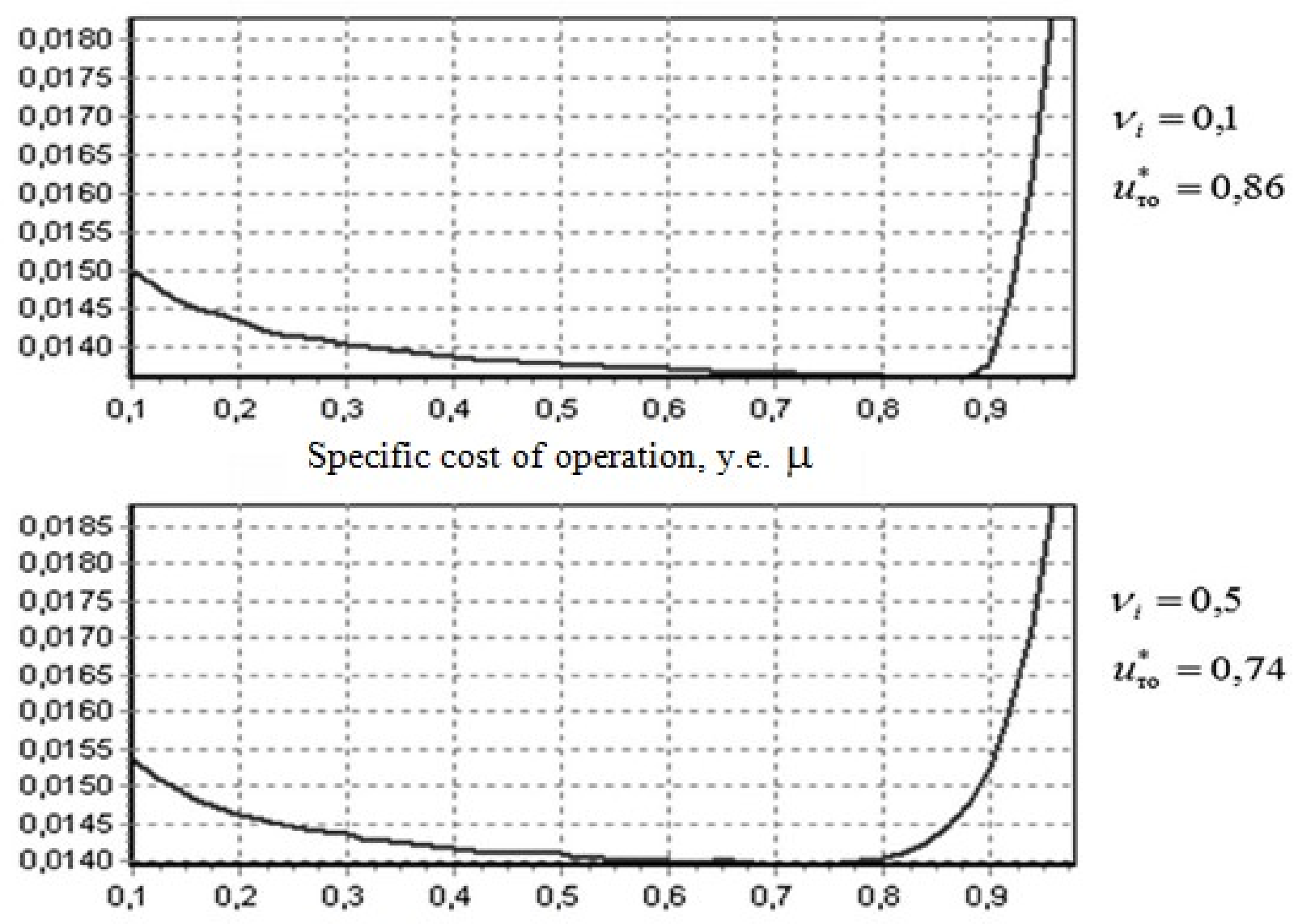

Specific cost of operation, y.e. $\mu$

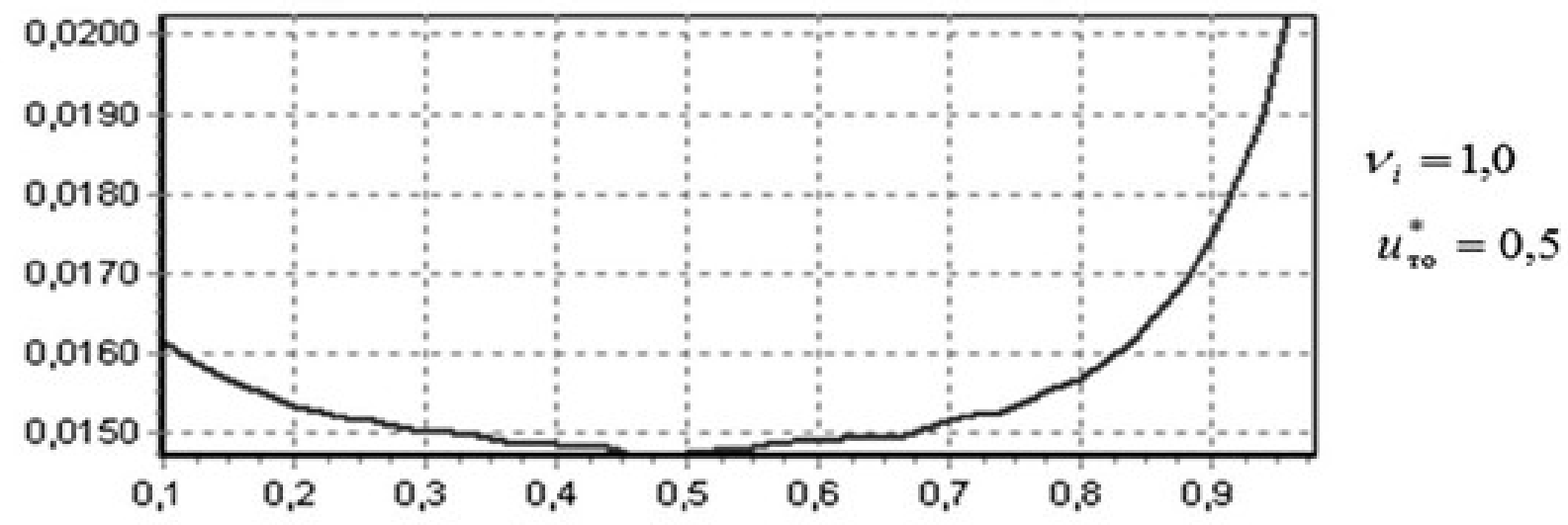

Figure 1 - Schedules of dependence $c_{\text {уд }}$ on a level MS $u_{\text {то }}$ at various values $v_{i}$

(object Test-1, $T_{\mathrm{K}}=1000 \mathrm{~h}$ )

$T_{\mathrm{K}}: 500 \mathrm{~h}, 1000 \mathrm{~h}$ and $1500 \mathrm{~h}$.

On fig. 1 schedules of dependence specific cost of operation $c_{\text {уд }}\left(E_{\text {то }}, u_{\text {то }}, T_{\mathrm{K}}\right)$ from $u_{\text {то }}$ are shown at $T_{\mathrm{K}}=1000 \mathrm{~h}$ for three values of factor of a variation $v: 0,1 ; 0,5 ; 1,0$.

Under schedules it is visible, that at increase in factor of a variation $v$ optimum value of a level MS $u_{\mathrm{To}}^{*}$ is displaced in area of smaller values.
Schedules fig. 1 are resulted only for an illustration of a kind of received results. On set of all results of calculations for object Test-1, received in the given research, the schedules shown on fig. 2 and have been constructed. Similar schedules have been received and for other test objects. As a whole their character similar to schedules for object Test-1. On fig. 2 for an example the same schedules for object Test -4 are resulted. 


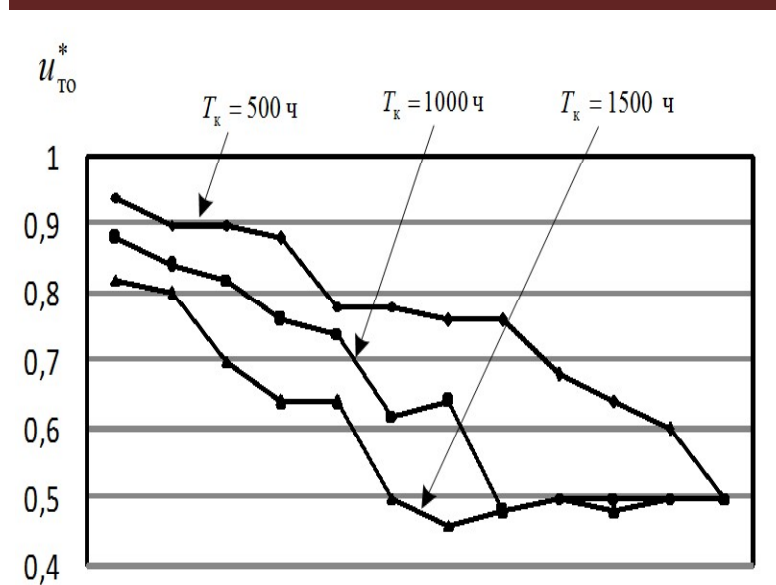

$\begin{array}{lllllllllllll}0,1 & 0,2 & 0,3 & 0,4 & 0,5 & 0,6 & 0,7 & 0,8 & 0,9 & 1 & 1,2 & 1,4 & v_{i}\end{array}$ a) object Test-1

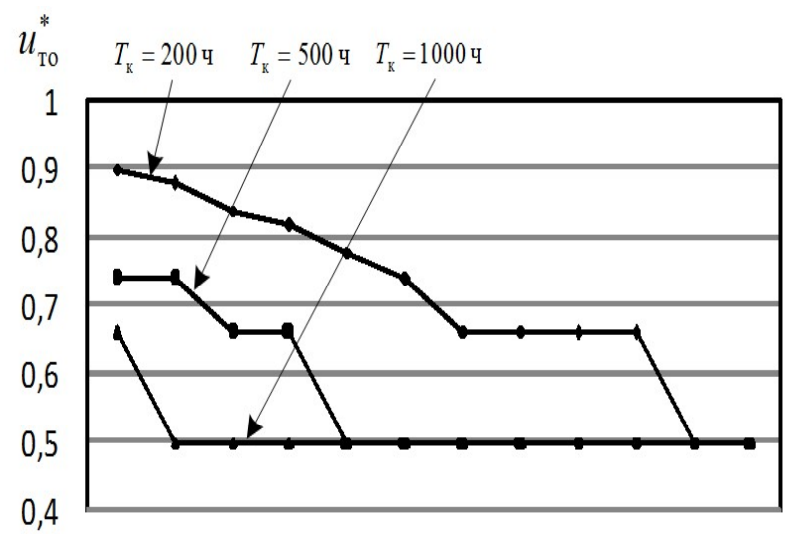

$\begin{array}{lllllllllllll}0,1 & 0,2 & 0,3 & 0,4 & 0,5 & 0,6 & 0,7 & 0,8 & 0,9 & 1 & 1,2 & 1,4 & v_{i}\end{array}$ b) object Test-4

Figure 2 - Schedules of dependence optimums level MS $u_{\mathrm{To}}^{*}$ from size of factor variation $v_{i}$ at various values of periodicity of the control $T_{\mathrm{\kappa}}$

Conclusions. As a whole by results of carried out brief research it is possible to draw such conclusions:

1) The general reason that the less size of factor of a variation of a casual operating time to refusal of served elements, the great should be opti- mum value of a level MS $u_{\mathrm{ro}}^{*}$

2) As for served elements the size of factor of a variation $v_{i}$, as a rule, is much less 1 (see table 1), optimum levels MS $u_{\text {To } i}^{*}$ for various elements should be defined separately;

Table 1 - Generalized estimations of factors variation of various physical processes

\begin{tabular}{|l|l|l|}
\hline $\begin{array}{l}\text { Kind of process deg- } \\
\text { radations }\end{array}$ & $\begin{array}{l}\text { Factor of variation } \\
\text { process of destruc- } \\
\text { tion }\end{array}$ & The name of the elements, exposed to destruction \\
\hline $\begin{array}{l}\text { Weariness (multicy- } \\
\text { clic) }\end{array}$ & $0,40-1,00$ & $\begin{array}{l}\text { Case details, bearings rolls, shaft, axes, springs, rods, } \\
\text { bolts, etc. }\end{array}$ \\
\hline $\begin{array}{l}\text { Deterioration (me- } \\
\text { chanics-chemical) }\end{array}$ & $0,20-0,50$ & Bearings of sliding, shaft, axes directing, plugs, etc. \\
\hline Ageing & $0,40-1,00$ & $\begin{array}{l}\text { Elements and details from metals, polymers, rubber } \\
\text { technical products, condensation, semiconductors, etc. }\end{array}$ \\
\hline $\begin{array}{l}\text { Electric (electroliz, } \\
\text { migration of charges, } \\
\text { electrodiffusion) }\end{array}$ & $0,70-1,50$ & $\begin{array}{l}\text { Semi-conductor devices, integrated schemes, conden- } \\
\text { sers and other products of electronic technics. }\end{array}$ \\
\hline
\end{tabular}

The choice of numerical value of factor variation from the specified range in each concrete case can be carried out in view of following general reasons: the more on the average the attitude of loading to a limit of endurance (durability), the is less factor of a variation and on the contrary, that is, the factor of loadings there is less, the factor of a variation is more.

1) If factors of a variation operating time to refusal of served elements are close to 1, an optimum level MS for them is value $u_{\mathrm{To} i}^{*}=0,5$. 


\section{References}

1. Стрельников В.П., Федухин А.В. Оценка и прогнозирование надежности электронных элементов и систем. - К.: Логос, 2002. - 486 с.

2. Банзак Г.В. Аналіз математичних моделей безвідмовності виробів радіоелектронної техніки / Г.Б.Жиров, В.В.Крихта, Г.В.Банзак // II - науково-практична конференція молодих науковців i студентів "Інформаційно-вимірювальні технології, технічне регулювання та менеджмент якості". - Одеса. - С.62-63.

Г. В. Банзак, к.т.н., О. В. Банзак, к.т.н., О. И. Лещенко, к.т.н.

\section{ВЛИЯНИЕ КОЭФФИЦИЕНТА ВАРИАЦИИ НА ВЕЛИЧИНУ ОПТИМАЛЬНОГО УРОВНЯ ТЕХНИЧЕСКОГО ОБСЛУЖИВАНИЯ}

В статье предложена имитационная статистическая модель в качестве модели отказов обслуживаемых элементов на основе DN-распределения. Исследования произведены в режиме моделирования технического обслуживания „, по состоянию” с постоянной периодичностью контроля. По результатам проведенных исследований подтверждается общее соображение о том, что чем меньше величина коэффичиента вариации случайной наработки до отказа обслуживаемых элементов, тем большим долюно быть оптимальное значение уровня технического обслуживания.

Ключевые слова: коэффициент вариачии, обслуживаемые элементы, значение уровня, техническое обслуживание.

Г. В. Банзак, к.т.н., О. В. Банзак, к.т.н., О. І. Лещенко, к.т.н.

\section{ВПЛИВ КОЕФЩІЕНТА ВАРІАЦЇ̈ НА ВЕЛИЧИНУ ОПТИМАЛЬНОГО РІВНЯ ТЕХНІЧНОГО ОБСЛУГОВУВАННЯ}

У статті запропонована імітаційна статистична модель як модель відмов елементів, шо обслуговують, на основі $D N-$ розподілу. Дослідження зроблені в режимі моделювання технічного обслуговування „,по стану” з постійною періодичністю контролю. За результатами проведених досліджень підтверджується загальне міркування про те, що чим менше величина коефіцієнта варіачії випадкового наробітку до відмови елементів, що обслуговують, тим більшим повинне бути оптимальне значення рівня технічного обслуговування.

Ключові слова: коефічіснт варіації, що обслуговують елементи, значення рівня, технічне обслуговування. 